University of South Carolina

Scholar Commons

7-26-2012

\title{
Solid Oxide Fuel Cells with both High Voltage and Power Output by Utilizing Beneficial Interfacial Reaction
}

Chao Su

Zongping Shao

Ye Lin

University of South Carolina - Columbia, linye@mailbox.sc.edu

Yuzhou Wu

Huanting Wang

Follow this and additional works at: https://scholarcommons.sc.edu/emec_facpub

Part of the Catalysis and Reaction Engineering Commons

\section{Publication Info}

Published in Physical Chemistry Chemical Physics, Volume 14, Issue 35, 2012, pages 12173-12181.

(c) Physical Chemistry Chemical Physics, 2012, Royal Society of Chemistry.

Su, C., Shao, Z., Lin, Y., Wu, Y., Wang, H. (2012). Solid Oxide Fuel Cells with both High Voltage and Power Output by Utilizing Beneficial Interfacial Reaction. Physical Chemistry Chemical Physics, 14(77),

12173-12181.

http://dx.doi.org/10.1039/C2CP41166K

This Article is brought to you by the Mechanical Engineering, Department of at Scholar Commons. It has been accepted for inclusion in Faculty Publications by an authorized administrator of Scholar Commons. For more information, please contact digres@mailbox.sc.edu. 


\title{
Solid oxide fuel cells with both high voltage and power output by utilizing beneficial interfacial reaction $\dagger$
}

\author{
Chao Su, ${ }^{a}$ Zongping Shao, ${ }^{* a b}$ Ye Lin, ${ }^{a}$ Yuzhou $\mathrm{Wu}^{b}$ and Huanting Wang ${ }^{b}$ \\ Received 11th April 2012, Accepted 25th July 2012 \\ DOI: $10.1039 / \mathrm{c} 2 \mathrm{cp} 41166 \mathrm{k}$
}

An intriguing cell concept by applying proton-conducting oxide as the ionic conducting phase in the anode and taking advantage of beneficial interfacial reaction between anode and electrolyte is proposed to successfully achieve both high open circuit voltage (OCV) and power output for SOFCs with thin-film samarium doped ceria (SDC) electrolyte at temperatures higher than $600{ }^{\circ} \mathrm{C}$. The fuel cells were fabricated by conventional route without introducing an additional processing step. A very thin and dense interfacial layer $(2-3 \mu \mathrm{m})$ with compositional gradient was created by in situ reaction between anode and electrolyte although the anode substrate had high surface roughness $(>5 \mu \mathrm{m})$, which is, however, beneficial for increasing triple phase boundaries where electrode reactions happen. A fuel cell with $\mathrm{Ni}-\mathrm{BaZr}_{0.4} \mathrm{Ce}_{0.4} \mathrm{Y}_{0.2} \mathrm{O}_{3}$ anode, thin-film SDC electrolyte and $\mathrm{Ba}_{0.5} \mathrm{Sr}_{0.5} \mathrm{Co}_{0.8} \mathrm{Fe}_{0.2} \mathrm{O}_{3-\delta}$ (BSCF) cathode has an OCV as high as $1.022 \mathrm{~V}$ and delivered a power density of $462 \mathrm{~mW} \mathrm{~cm}^{-2}$ at $0.7 \mathrm{~V}$ at $600{ }^{\circ} \mathrm{C}$. It greatly promises an intriguing fuel cell concept for efficient power generation.

\section{Introduction}

Our current society relies too heavily on fossil fuels. With increasing environmental pollution and global warming effect from their excessive and low efficient burning, nowadays people are more and more concerned about finding new energy sources and innovative energy technologies with improved efficiency for a sustainable future. Solid oxide fuel cells (SOFCs) are fascinating electrochemical energy conversion devices with the advantageous features of high efficiency, low emissions, fuel flexibility and high value of exhaust heat, which are believed to have an important role in future clean power generation. ${ }^{1-3}$

SOFCs can be divided into oxide ion conducting ones and proton-conducting ones based on the conducting mechanism of electrolyte (Fig. S1, ESI $\dagger$ ). In those cells, anodes are typically composed of metallic nickel and an ionic conducting phase in a mutual percolating way. The ionic conducting phase is introduced with the purpose of improving the electrode performance by effectively extending the electrode-electrolytegas triple phase boundary (TPB) where the electrochemical

\footnotetext{
${ }^{a}$ State Key Laboratory of Materials-Oriented Chemical Engineering, College of Chemistry \& Chemical Engineering, Nanjing University of Technology, No. 5 Xin Mofan Road, Nanjing 210009, P.R. China. E-mail: shaozp@njut.edu.cn; Fax: +862583172242;

Tel: + 862583172256

${ }^{b}$ Department of Chemical Engineering, Monash University, Clayton, VIC 3800, Australia

$\dagger$ Electronic supplementary information (ESI) available: Schematic of SOFC operating principle, SEM images, $I-V$ and $I-P$ polarization curves and EIS. See DOI: 10.1039/c2cp41166k
}

reactions for fuel oxidation occur. Interfacial reaction between cell components typically leads to the formation of an unexpected insulating layer which deteriorates cell performance. ${ }^{4,5}$ Thus, in order to avoid potential interfacial reaction, the composition of the ionic conducting phase in the anode was always the same as the electrolyte. Interestingly, recently, we also demonstrated that by tailoring the material composition, the interfacial reaction may create a beneficial effect for cathode performance. ${ }^{6}$

Conventional SOFCs are composed of oxide ion conducting yttria-stabilized zirconia (YSZ) electrolyte, $\mathrm{La}_{0.8} \mathrm{Sr}_{0.2} \mathrm{MnO}_{3}$ (LSM) perovskite oxide cathode and $\mathrm{Ni}-\mathrm{YSZ}$ cermet anode, and are typically operated at around $1000{ }^{\circ} \mathrm{C}$ to ensure high cell power output, which introduces numerous drawbacks including fast cell degradation rate and high cell material and maintenance cost and difficult sealing. ${ }^{1,7}$ In order to expand cell lifetime and achieve cost effectiveness, it is generally accepted that the cell operating temperature should be decreased to the intermediate range $\left(500-800{ }^{\circ} \mathrm{C}\right) .{ }^{8-10}$ Low ionic conductivity of electrolyte and poor activity of cathode for oxygen reduction are the new emerging problems for conventional SOFCs when operating at reduced temperatures.

Nowadays, there is increasing interest in proton-conducting SOFCs created by the lower activation energy for proton diffusion than oxide ion. ${ }^{11-14}$ However, the power density of such SOFCs is still relatively low due to the lack of high-performance cathodes. Water is formed at the cathode in proton-conducting SOFCs, which may create a block for oxygen surface diffusion due to its higher polarity than molecular oxygen. In addition, most cathode materials can react easily with proton-conducting electrolytes, which show the same perovskite-type lattice structure. 
Both factors introduce a big challenge in the development of high performance cathodes for proton-conducting SOFCs. People also try to increase the low-temperature performance of SOFCs by exploiting alternative oxide ion conducting electrolytes. ${ }^{15-17}$ Doped ceria have higher ionic conductivity and much better compatibility with most high-performance cobalt-based electrodes than stabilized zirconia. ${ }^{7}$ Unfortunately, they have partial electronic conductivity at elevated temperature and reducing atmosphere. ${ }^{18}$ Although high open circuit voltage (OCV) can be obtained for fuel cells with thick electrolytes, as demonstrated by both experiment and modeling, SOFCs with thin-film doped ceria electrolytes have non-negligible leaked current under fuel cell operating conditions at $>600{ }^{\circ} \mathrm{C}$, resulting in both low OCV and reduced fuel efficiency. ${ }^{19}$ Thus, they are usually operated at $<600{ }^{\circ} \mathrm{C}$, which introduces a big challenge for the cathode development. To achieve high OCV at $>600{ }^{\circ} \mathrm{C}$ for fuel cell with doped ceria electrolyte, an electronic blocking layer with protonic conduction properties was applied by Hibino et $a l^{20,21}$ The same concept was also adopted by Xia et al. ${ }^{22}$ Although the OCV did improve effectively, the power output was relatively low. In addition, the complexity in fuel cell fabrication was greatly increased, in particular for a buffer layer with less than $10 \mu \mathrm{m}$, making it less cost effective. Recently, $\mathrm{Ni}-\mathrm{Ba}_{1+x} \mathrm{Zr}_{0.3} \mathrm{Ce}_{0.5} \mathrm{Y}_{0.2} \mathrm{O}_{3-\delta}$ hydrogen electrodes was reported as effective reduction barriers for reversible solid oxide cells based on doped ceria electrolyte thin film by Peng et al., but the cell performance was not sufficiently high. ${ }^{23}$

Herein, we report an intriguing SOFC concept by applying SDC as electrolyte while a proton-conducting perovskite as the ionic conducting phase in anode, as shown in Fig. $1 .^{24}$ Under operation, molecular hydrogen is oxidized to protons, while molecular oxygen is reduced to oxygen anions, then oxygen anions migrate through the electrolyte to the anode, and react with proton to form water. This SOFC showed both high OCV and power density at temperatures higher than $600{ }^{\circ} \mathrm{C}$. An interfacial reaction between the electrolyte and the anode was created during high temperature sintering, which effectively blocked the partial electronic conductivity of SDC electrolyte. The cell demonstrated both advantages of proton-conducting SOFCs and oxide ion conducting SOFCs, while eliminating their disadvantages. This cell configuration, which is simple as it does not introduce any additional steps for cell fabrication as compared with conventional SOFCs, is also highly cost effective. It introduces a new way to develop high-performance SOFC for clean power generation.

\section{Experimental}

\section{Powder synthesis}

BZCY4, SDC and BSCF powders were all synthesized by an EDTA-citrate complexing sol-gel process. The appropriate metal nitrates were dissolved in water, and a combination of EDTA and citric acid served as complexing agents. ${ }^{25}$ After stirring and heating, a clear gel was obtained, which was held at $240{ }^{\circ} \mathrm{C}$ for several hours and finally calcined under stagnant air at $1000{ }^{\circ} \mathrm{C}$ (BZCY4), $800{ }^{\circ} \mathrm{C}$ (SDC) or $950{ }^{\circ} \mathrm{C}$ (BSCF) for $5 \mathrm{~h}$ to obtain the pure phase oxides.

\section{Fuel cell fabrication}

The anode-supported thin-film electrolyte cells were fabricated by the dry pressing/sintering of the anode-electrolyte dual layer and spray deposition/firing of the cathode layer. ${ }^{25}$ Anode powder, composed of $60 \mathrm{wt} \% \mathrm{NiO}$ and $40 \mathrm{wt} \% \mathrm{BZCY} 4$ (or SDC) was first dry pressed into a substrate disk, then BZCY4 (or SDC) powder was well-distributed over the anode surface and co-pressed with the anode to form the green dual layer cell, which was then sintered at $1450{ }^{\circ} \mathrm{C}$ for $5 \mathrm{~h}$ in air. The BSCF cathode slurry was sprayed on the central surface of the electrolyte in a round shape and fired at $1000{ }^{\circ} \mathrm{C}$ in air for $2 \mathrm{~h}$. The effective geometric surface area is typically $\sim 0.48 \mathrm{~cm}^{2}$.

\section{Fuel cell electrochemical characterization}

The $I-V$ and $I-P$ polarization curves of the cells were obtained using a Keithley 2420 source meter based on the four-probe configuration. The single cell was sealed in a quartz tube using silver paste. $3 \%$ water humidified $\mathrm{H}_{2}$ as the fuel was fed into the anode chamber at a flow rate of $80 \mathrm{~mL} \mathrm{~min}^{-1}$ [Standard Temperature Pressure, STP], while the cathode side of the fuel cell was exposed to ambient air. The electrode performance was investigated by a complete cell configuration, and the electrochemical impedance spectra (EIS) of the cell was performed using a Solartron 1260A frequency response analyzer in combination with a Solartron 1287 potentiostat under OCV condition from 0.1 to $1000 \mathrm{kHz}$.

\section{Other characterizations}

The phase structure of the samples was observed by an X-ray diffractometer (XRD, Bruker D8 Advance). The scans were performed in the $2 \theta$ range $20-90^{\circ}$. The microstructure and the elemental distribution of the cross section of the fuel cells were

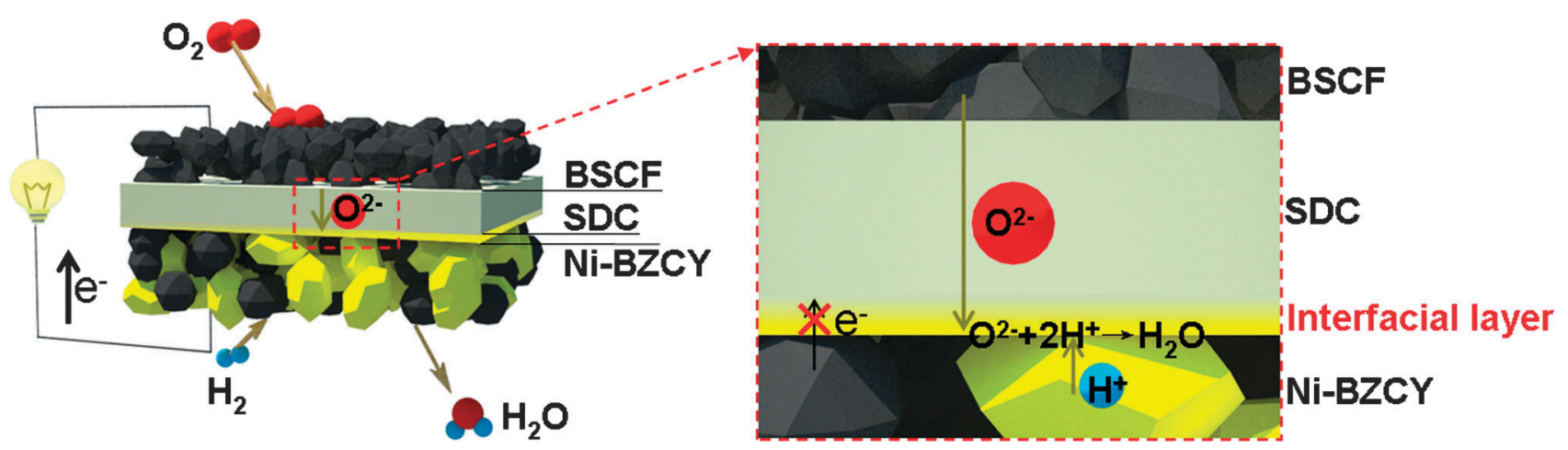

Fig. 1 Schematic of the intriguing SOFC operating principle. 
examined by an environmental scanning electron microscope (ESEM, Quanta-200) equipped with an energy dispersive $\mathrm{X}$-ray analyzer (EDX). The surface topography of the sintered NiO-BZCY4 anode substrate was obtained using Bruker ContourGT-K1 bench top 3D optical microscope surface profiling systems. The coke resistance of anode materials was analyzed by oxygen- temperature programmed oxidation $\left(\mathrm{O}_{2}-\mathrm{TPO}\right)$. Approximately $0.01 \mathrm{~g}$ anode powder after treatment was placed into a U-type quartz reactor with an inner diameter of $\sim 4 \mathrm{~mm}$. Pure oxygen at the flow rate of $15 \mathrm{~mL} \mathrm{~min}^{-1}$ [STP] was then introduced to the reactor. The deposited carbon over the powder surface was then progressively oxidized into $\mathrm{CO}_{2}$. The effluent gas from the reactor was connected with a Hiden QIC-20 Mass spectrometer (MS) for in situ monitoring of the concentration variation of $\mathrm{CO}_{2}$.

\section{Results and discussion}

We first fabricated and tested an anode-supported SOFC composed of SDC electrolyte $(25 \mu \mathrm{m}), \mathrm{NiO}-\mathrm{SDC}$ cermet anode (NiO to SDC weight ratio of $60: 40$ ) and $\mathrm{Ba}_{0.5} \mathrm{Sr}_{0.5} \mathrm{Co}_{0.8} \mathrm{Fe}_{0.2} \mathrm{O}_{3-\delta}$ (BSCF) cathode. Fig. S2 (ESI $\dagger$ ) presents a SEM image of a typical single cell from the cross-sectional view. The electrolyte with a thickness of $25 \mu \mathrm{m}$ was well densified after sintering at $1450{ }^{\circ} \mathrm{C}$. Fig. S3 (ESI $\left.\dagger\right)$ shows typical current-voltage $(I-V)$ and current-power $(I-P)$ polarization curves of the cell operating under the conditions of ambient air as cathode atmosphere and $3 \%$ water humidified hydrogen as fuel. The cell delivered peak power densities (PPDs) of 319, 547, 812, 979, 1019, and $908 \mathrm{~mW} \mathrm{~cm}^{-2}$ at 500, 550, 600, 650, 700 and $750{ }^{\circ} \mathrm{C}$, respectively, which are comparable to the literature results for similar cells. $^{25,26}$ The high power outputs can be explained by the high ionic conductivity of SDC electrolyte and excellent electrochemical catalytic activity of BSCF cathode for oxygen reduction reaction (ORR) as well as good chemical compatibility between BSCF cathode and SDC electrolyte, as demonstrated by low ohmic resistances and electrode polarization resistances of the cell tested under open circuit condition (Fig. S4, ESI $\dagger$ ). However, as expected, the cell shows low OCV of only $0.862 \mathrm{~V}$ at $600{ }^{\circ} \mathrm{C}$, compared with $1.136 \mathrm{~V}$, for that calculated based on the Nernst equation. With the increase of operating temperature, the cell OCV is quickly decreased to only $0.717 \mathrm{~V}$ at $750{ }^{\circ} \mathrm{C}$. The fast increase in leaked current density resulted in a lower power output at $750{ }^{\circ} \mathrm{C}$ $\left(908 \mathrm{~mW} \mathrm{~cm}^{-2}\right)$ than at $700{ }^{\circ} \mathrm{C}\left(1019 \mathrm{~mW} \mathrm{~cm}^{-2}\right)$.

To demonstrate the effectiveness of adopting a protonconducting barium-containing perovskite oxide as the ionic conducting phase in the anode in improving OCV of SOFC with thin-film doped ceria electrolyte, a NiO- $\mathrm{BaZr}_{0.4} \mathrm{Ce}_{0.4} \mathrm{Y}_{0.2} \mathrm{O}_{3}$ (BZCY4) supported SDC electrolyte $(25 \mu \mathrm{m})$ SOFC with BSCF cathode was also fabricated and tested for power generation. BZCY4 was selected for its high chemical stability against $\mathrm{CO}_{2}$ and water vapor. ${ }^{27,28}$ The co-sintering for the anode and the electrolyte layer was also conducted at $1450{ }^{\circ} \mathrm{C}$. Fig. 2a shows $I-V$ and $I-P$ polarization curves of the cell at various temperatures with $3 \%$ water humidified hydrogen as fuel and ambient air as the cathode atmosphere. It shows high OCVs at all investigated temperatures, reaching $0.960 \mathrm{~V}$ at $750{ }^{\circ} \mathrm{C}$, compared with only $0.717 \mathrm{~V}$ for a similar SOFC with
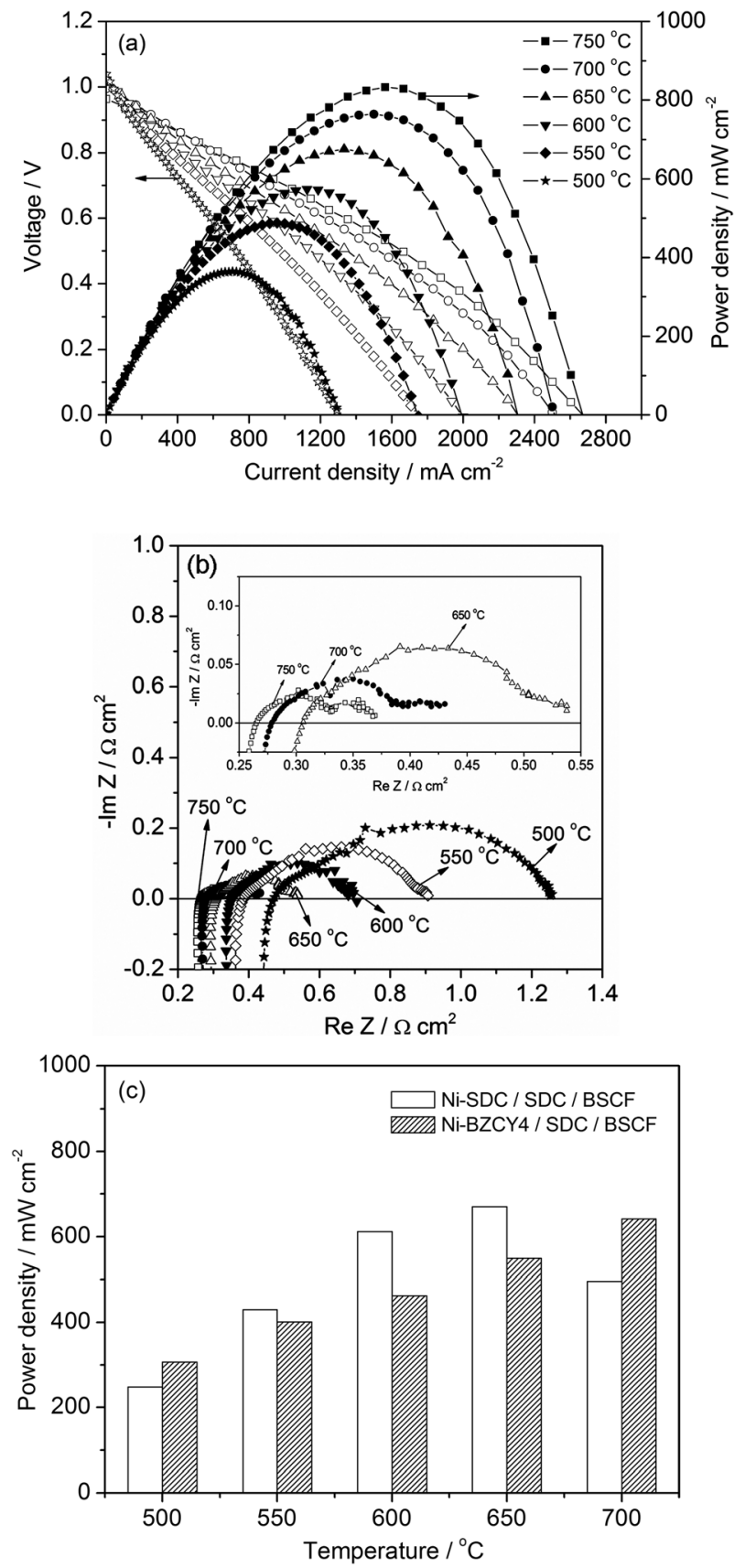

Fig. 2 (a) The $I-V$ and $I-P$ polarization curves of the SOFC with a configuration of $\mathrm{Ni}-\mathrm{BZCY} 4|\mathrm{SDC}| \mathrm{BSCF}$ at various temperatures with $3 \%$ water humidified hydrogen as fuel and ambient air as the cathode atmosphere. (b) The electrochemical impedance spectroscopies of this SOFC tested under open circuit condition at various temperatures. (c) The power densities of two types of SOFCs under a cell voltage of $0.7 \mathrm{~V}$ at various temperatures.

SDC as the material for both electrolyte and the ionic conducting phase in the anode (Fig. S3, ESI $\dagger$ ). The SOFC also demonstrated promising power outputs with PPDs of 364, $488,574,676,765$ and $833 \mathrm{~mW} \mathrm{~cm}^{-2}$ at 500, 550, 600, 650, 700 and $750{ }^{\circ} \mathrm{C}$, respectively. As shown in Fig. 2b, the total electrode polarization resistance (a sum of anodic and cathodic polarization resistances) under OCV condition is only 0.10 and $0.35 \Omega \mathrm{cm}^{2}$ at 750 and $600{ }^{\circ} \mathrm{C}$, respectively. 
In addition, the cell also shows low electrolyte ohmic resistances with values of $0.26-0.35 \Omega \mathrm{cm}^{2}$ between 600 and $750{ }^{\circ} \mathrm{C}$. As compared to the conventional Ni-SDC anode supported thin-film SDC electrolyte SOFC, the Ni-BZCY4|SDC $\mid$ BSCF cell showed slightly lower PPDs at corresponding temperatures, for example, at $600{ }^{\circ} \mathrm{C}$ they are 812 and $574 \mathrm{~mW} \mathrm{~cm}^{-2}$ for the SOFCs with SDC and BZCY4 as the ionic conducting phases in the electrolyte and anode, respectively. However, for practical application, the SOFCs are usually operated at a cell voltage of around $0.7 \mathrm{~V}$. Under such conditions the two cells delivered similar power outputs at corresponding temperatures (Fig. 2c), i.e., the power densities for the Ni-SDC supported SOFC are $248\left(500{ }^{\circ} \mathrm{C}\right), 429$ $\left(550{ }^{\circ} \mathrm{C}\right), 612\left(600{ }^{\circ} \mathrm{C}\right), 670\left(650{ }^{\circ} \mathrm{C}\right)$ and $496 \mathrm{~mW} \mathrm{~cm}{ }^{-2}\left(700{ }^{\circ} \mathrm{C}\right)$, while the corresponding values are $306\left(500{ }^{\circ} \mathrm{C}\right), 401\left(550{ }^{\circ} \mathrm{C}\right), 462$ $\left(600{ }^{\circ} \mathrm{C}\right), 550\left(650{ }^{\circ} \mathrm{C}\right)$ and $641 \mathrm{~mW} \mathrm{~cm}^{-2}\left(700{ }^{\circ} \mathrm{C}\right)$ for the Ni-BZCY4 supported SOFC. By applying $\mathrm{BaZr}_{0.1} \mathrm{Ce}_{0.7} \mathrm{Y}_{0.2} \mathrm{O}_{3}$ (BZCY1), a protonic conducting oxide with higher conductivity than BZCY4. ${ }^{28,29}$ As the ionic conducting phase in the anode, the cell delivered even higher power outputs. As shown in Fig. 3, a PPD as high as $1019 \mathrm{~mW} \mathrm{~cm}^{-2}$ was achieved at $700{ }^{\circ} \mathrm{C}$, and power output of $955 \mathrm{~mW} \mathrm{~cm}^{-2}$ was still reached at a cell voltage of $0.7 \mathrm{~V}$ at $600{ }^{\circ} \mathrm{C}$.

For comparison, we also fabricated and evaluated a protonic conducting SOFC with $\mathrm{Ni-BZCY4}$ anode and thin-film BZCY4 electrolyte $(25 \mu \mathrm{m})$ and BSCF cathode. Fig. S5 (ESI $\dagger$ ) is the SEM photo from cross-sectional view of the single cell. Some enclosed pores were still detected within the BZCY4 electrolyte layer even when the electrolyte was sintered at $1450{ }^{\circ} \mathrm{C}$, while it was highly densified for the SDC electrolyte also sintered at $1450{ }^{\circ} \mathrm{C}$ (Fig. S2, ESI $\dagger$ ). It clearly demonstrated that the sintering of BZCY4 is much more difficult than SDC. However, the poor sintering of BZCY4 promises it as an ionic conducting phase in the anode since the electrode should keep sufficient porosity for free gas diffusion. $I-V$ and $I-P$ polarization curves of the proton-conducting cell were measured with the results shown in Fig. S6 (ESI $\dagger$ ). The cell gives high cell voltages of $1.096-0.960 \mathrm{~V}$ between 600 and $750{ }^{\circ} \mathrm{C}$, slightly larger than those of the $\mathrm{Ni}-\mathrm{BZCY} 4|\mathrm{SDC}| \mathrm{BSCF}$ cell, while the power outputs of the protonic conducting SOFC are much lower with the PPDs of only 127, 176, 218, 253, 290 and $334 \mathrm{~mW} \mathrm{~cm}^{-2}$ at 500, 550, 600, 650, 700 and $750{ }^{\circ} \mathrm{C}$, respectively.

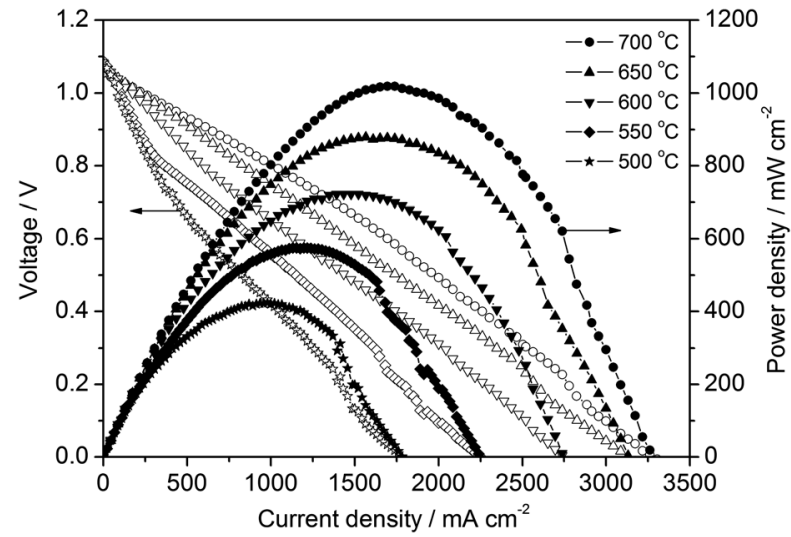

Fig. $3 I-V$ and $I-P$ polarization curves of the SOFC with a configuration of $\mathrm{Ni}-\mathrm{BZCY} 1|\mathrm{SDC}| \mathrm{BSCF}$ at various temperatures with $3 \%$ water humidified hydrogen as fuel and ambient air as the cathode atmosphere.
Both ohmic resistance and electrode polarization resistance of the proton-conducting SOFC with Ni-BZCY4 anode and BZCY4 electrolyte are much higher than the Ni-BZCY4 SDC $\mid$ BSCF cell at corresponding temperatures (Fig. S7, $\mathrm{ESI} \dagger)$. This was due to the interfacial reaction between BZCY4 and $\mathrm{BSCF}$, which resulted in significantly reduced protonic conductivity of the BZCY4 electrolyte and also increased polarization resistance of the electrode. Similar results regarding the interfacial reaction between $\mathrm{BaCe}_{0.9} \mathrm{Y}_{0.1} \mathrm{O}_{2.95}$ (BCY) and $\mathrm{BSCF}$ was reported in our previous study. ${ }^{30}$ It has also been demonstrated that BSCF is not an appropriate cathode for the cell with zirconium-based electrolyte because of the phase reaction. ${ }^{31}$ The above results strongly demonstrated the superiority of the cell we report for achieving both high OCVs and power outputs.

We further found that high OCV was obtained for the cells when their anode and electrolyte were co-sintered at a wide range of temperatures. Table 1 gives a comparison of OCV and PPDs at various operating temperatures for $\mathrm{Ni}-\mathrm{BZCY} 4|\mathrm{SDC}| \mathrm{BSCF}$ cells in which the NiO-BZCY4 anode and SDC electrolyte were co-sintered at 1350, 1400, 1450 and $1500{ }^{\circ} \mathrm{C}$, respectively. Although the power outputs of different cells varied somewhat, all cells demonstrated much improved OCV as compared to the similar $\mathrm{Ni}-\mathrm{SDC}|\mathrm{SDC}| \mathrm{BSCF}$ cell at corresponding temperature. A sintering temperature of $1450{ }^{\circ} \mathrm{C}$ was found to be optimal to achieve both high OCV and power output.

The improved OCVs suggest the partial electronic conductivity in SDC electrolyte of the Ni-BZCY4|SDC $\mid \mathrm{BSCF}$ cell

Table 1 The OCV and PPDs at various operating temperatures for $\mathrm{Ni}-\mathrm{BZCY} 4|\mathrm{SDC}| \mathrm{BSCF}$ cells in which the anode and electrolyte were co-sintered at $1350,1400,1450$ and $1500{ }^{\circ} \mathrm{C}$, respectively. The units of $\mathrm{OCV}$ and PPD are $\mathrm{V}$ and $\mathrm{mW} \mathrm{cm}^{-2}$, respectively

\begin{tabular}{|c|c|c|c|c|c|c|c|c|}
\hline \multirow{3}{*}{$\begin{array}{l}\text { Sintering } \\
\text { temperature }\left({ }^{\circ} \mathrm{C}\right)\end{array}$} & \multicolumn{8}{|c|}{ Operating temperature $\left({ }^{\circ} \mathrm{C}\right)$} \\
\hline & \multicolumn{2}{|l|}{750} & \multicolumn{2}{|l|}{700} & \multicolumn{2}{|l|}{650} & \multicolumn{2}{|l|}{600} \\
\hline & $\mathrm{OCV}$ & PPD & $\mathrm{OCV}$ & PPD & $\mathrm{OCV}$ & PPD & $\mathrm{OCV}$ & PPD \\
\hline 1350 & 0.97 & 814 & 0.99 & 716 & 1.00 & 638 & 1.01 & 530 \\
\hline 1400 & 0.95 & 823 & 0.97 & 743 & 0.99 & 651 & 1.00 & 557 \\
\hline 1450 & 0.96 & 833 & 1.00 & 765 & 1.01 & 676 & 1.02 & 574 \\
\hline 1500 & 0.96 & 813 & 0.97 & 736 & 0.99 & 626 & 1.02 & 506 \\
\hline
\end{tabular}

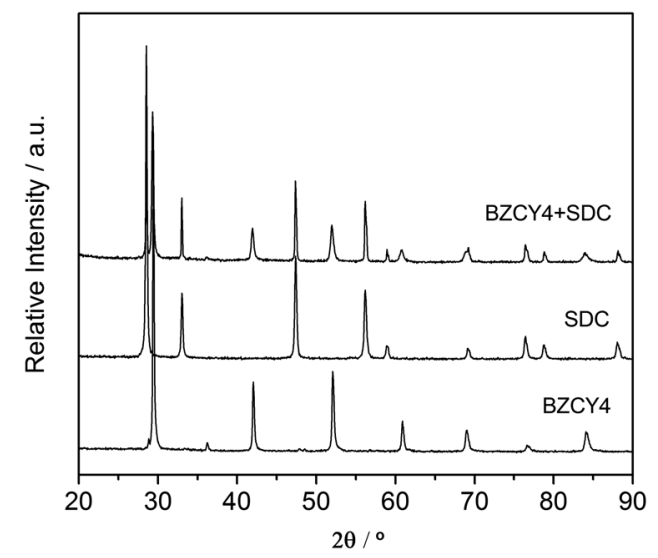

Fig. 4 The XRD patterns of the BZCY4, SDC and BZCY4+SDC mixture powder after firing at $1450{ }^{\circ} \mathrm{C}$ for $5 \mathrm{~h}$. BZCY4 and SDC were mixed well at a weight ratio of $50: 50$ by high energy ball milling. 
was effectively blocked. It is likely a certain type of interfacial reaction happened between $\mathrm{NiO}-\mathrm{BZCY} 4$ anode and SDC electrolyte which effectively blocked the electron transportation in the SDC electrolyte. To support this assumption, we first investigated the phase reaction between BZCY4 and SDC by powder reaction. Pure phase BZCY4 and SDC were mixed well at the weight ratio of 50 : 50 by high energy ball milling, then fired at $1450{ }^{\circ} \mathrm{C}$ (the same temperature for cell fabrication), and the powder was examined by room-temperature XRD. Shown in Fig. 4 are the XRD patterns of the BZCY4, SDC and BZCY4 + SDC mixture powder after firing at $1450{ }^{\circ} \mathrm{C}$. The mixture can be indexed well based on a physical mixture of a perovskite phase and a fluorite phase with the lattice parameters close to BZCY4 and SDC, respectively. It seems there was no serious solid-phase reaction between BZCY4 and SDC. However, diffraction peaks of the perovskite phase became broader after being calcined together with SDC. Previously we demonstrated that cation exchange could happen between BCY and other perovskite phases at elevated temperature with the formation of new phases with the lattice structure similar to the reactants. ${ }^{30}$ It was known that $\mathrm{Ba}, \mathrm{Ce}$ and $\mathrm{Sm}$ can form protonic conducting $\mathrm{BaCe}_{1-x} \mathrm{Sm}_{x} \mathrm{O}_{3-\delta}$ oxides, which are proton conductors with similar lattice parameters to BZCY4 perovskite. ${ }^{32}$ To give more information about the reaction between SDC and BZCY4 at high temperature, NiO-BZCY4 and SDC dense disks were separately fabricated by drying, pressing and sintering at $1450{ }^{\circ} \mathrm{C}$ for $5 \mathrm{~h}$. After surface polishing, they were piled face by face and co-sintered under a load at $1450{ }^{\circ} \mathrm{C}$ for $5 \mathrm{~h}$. Fig. 5 gives the average element composition of the SDC pellet after the sintering at selected areas near the surface in contact with $\mathrm{NiO}-\mathrm{BZCY} 4$, measured by EDX. A noticeable amount of $\mathrm{Ba}^{2+}$ was detected in the selected location near the SDC surface which

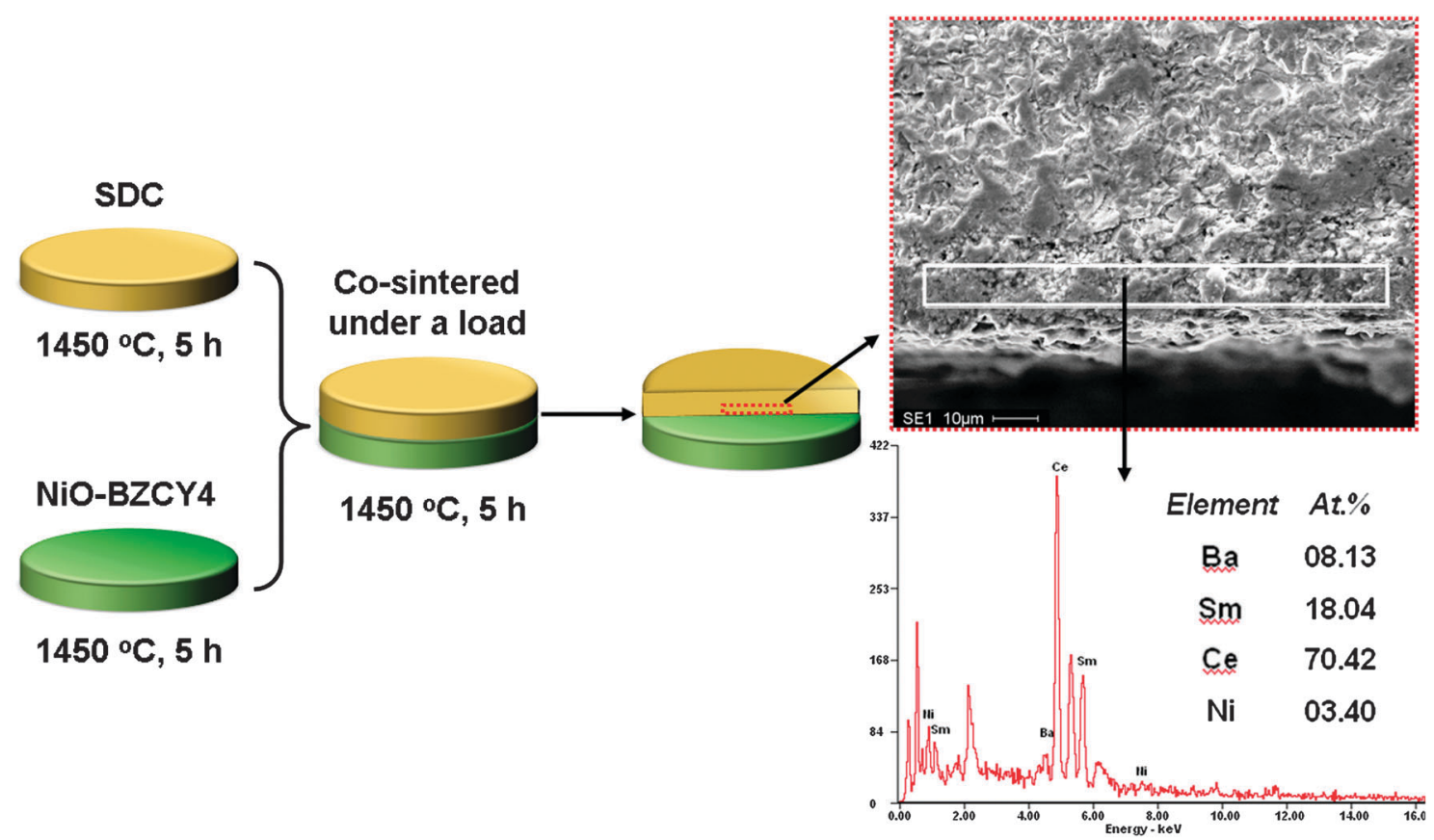

Fig. 5 The average element composition of the SDC pellet after the sintering at selected area near the surface in contact with NiO-BZCY4 pellet measured by EDX.
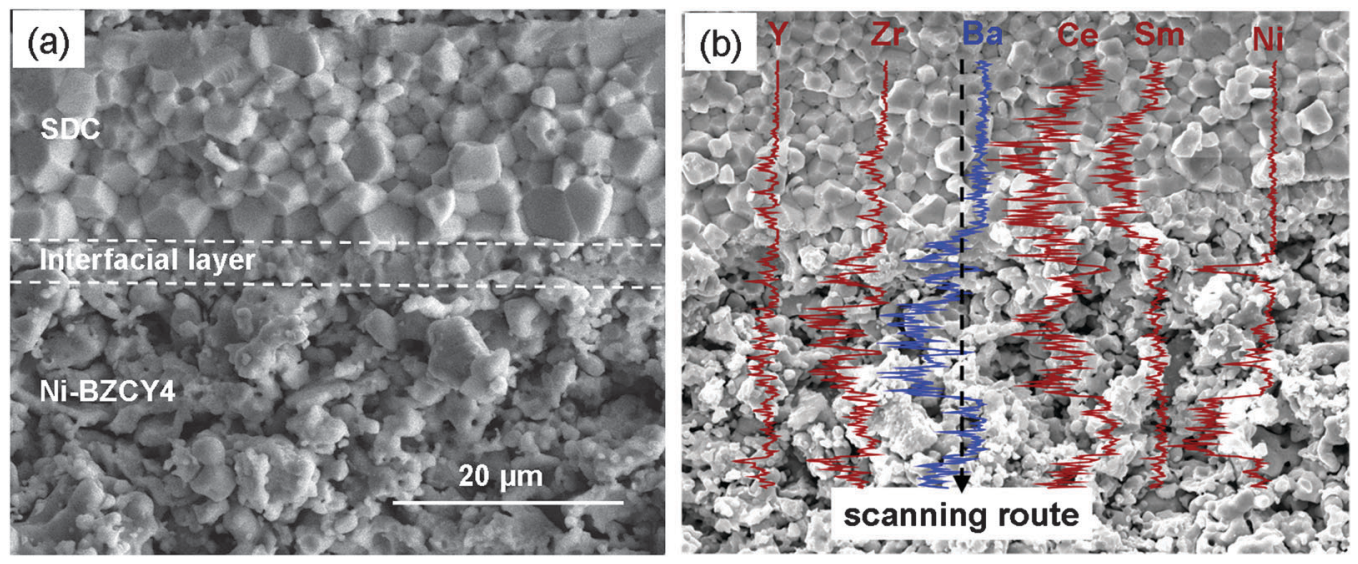

Fig. 6 (a) The SEM photo and (b) the linear EDX profiling of the Ni-BZCY4/SDC/BSCF cell after the cell performance test from the crosssectional view. 
was in contact with $\mathrm{NiO}-\mathrm{BZCY} 4$ pellet during the sintering. It further supported the diffusion of $\mathrm{Ba}^{2+}$ from the anode to the electrolyte during the cell sintering in the Ni-BZCY4|SDC|BSCF cell. Although some $\mathrm{Ni}^{2+}$ was also detected in the same location, it has much lower concentration than $\mathrm{Ba}^{2+}$. Previously, we demonstrated that there was strong chemical interaction between BZCY4 and $\mathrm{NiO}$ which effectively suppressed the diffusion of $\mathrm{NiO}$ during the sintering. ${ }^{33}$ Fig. 6 shows the SEM of the Ni-BZCY4|SDC $\mid$ BSCF cell after the cell performance test from the cross-sectional view. A dense interfacial layer with a thickness of around 2-3 $\mu \mathrm{m}$ was formed between Ni-BZCY4 anode and SDC electrolyte. The linear EDX profiling clearly demonstrated that a barium

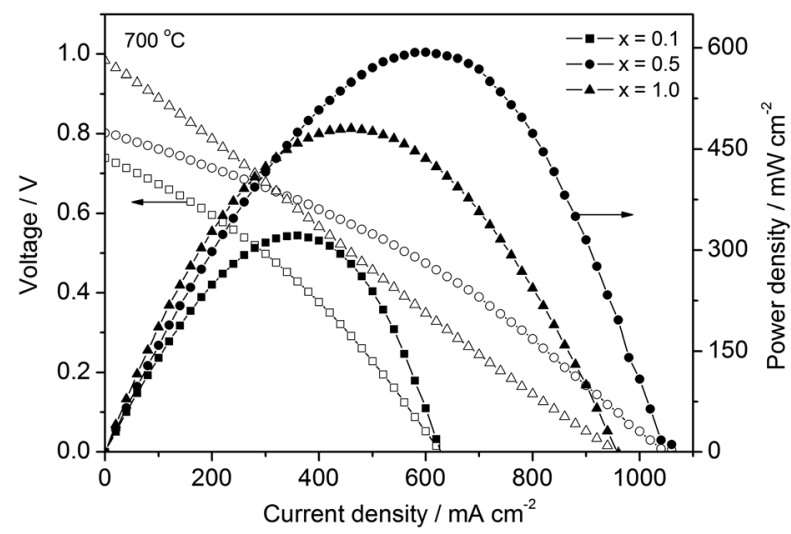

Fig. $7 \quad I-V$ and $I-P$ polarization curves of the $\mathrm{Ni}-\mathrm{Ba}_{x} \mathrm{Ce}_{0.8} \mathrm{Sm}_{0.2} \mathrm{O}_{3} \mid-$ $\mathrm{Ba}_{x} \mathrm{Ce}_{0.8} \mathrm{Sm}_{0.2} \mathrm{O}_{3} \mid \mathrm{BSCF}(x=0.1,0.5$ and 1$)$ cells sintered at $1450{ }^{\circ} \mathrm{C}$ for $5 \mathrm{~h}$ with $3 \%$ water humidified $\mathrm{H}_{2}$ as fuel and ambient air as the cathode atmosphere at the operating temperature of $700{ }^{\circ} \mathrm{C}$. concentration gradient appeared in this thin layer. A higher $\mathrm{Ba}^{2+}$ concentration was observed nearer to the Ni-BZCY4 anode layer. It suggests some $\mathrm{Ba}^{2+}$ diffused from the anode into the SDC electrolyte with the formation of a barium-containing transition layer.

To know the effect of $\mathrm{Ba}^{2+}$ diffusion on the OCV and power output of the cells, materials with the composition of $\mathrm{Ba}_{x} \mathrm{Ce}_{0.8^{-}}$ $\mathrm{Sm}_{0.2} \mathrm{O}_{3}(x=0.1,0.5$ and 1$)$ were synthesized and fuel cells with those materials as electrolytes were fabricated. Fig. 7 shows $I-V$ and $I-P$ curves of the corresponding cells with electrolyte thickness of around $25 \mu \mathrm{m}$ at $700{ }^{\circ} \mathrm{C}$. A steady increase in OCV was observed with $\mathrm{Ba}^{2+}$ content in the electrolyte. Clearly, the incorporation of $\mathrm{Ba}^{2+}$ into SDC increased the $\mathrm{OCV}$, in particular with the formation of $\mathrm{BaCe}_{0.8} \mathrm{Sm}_{0.2} \mathrm{O}_{3}$ perovskite which is a proton conductor with much lower electronic conductivity than SDC.

The reduced power output suggested the as-formed $\mathrm{BaCe}_{0.8} \mathrm{Sm}_{0.2} \mathrm{O}_{3}$ had lower ionic conductivity than SDC. Thus, it should be made as thin as possible to minimize the ohmic resistance. Shown in Fig. 8 is the microstructural morphology of the surface of a sintered NiO-BZCY4 anode substrate, prepared by the dry pressing method. It had high degree of surface roughness, reaching as much as $5 \mu \mathrm{m}$. It thus introduced great difficulty to obtain a thin blocking layer with good blocking effect. Indeed, Cheng et al. found that the Gd-doped ceria (GDC) buffering layer prepared by the slurry-coating method started to lose its protecting effect for avoiding the direct contact of a BSCF cathode with a YSZ electrolyte with the decrease of thickness. ${ }^{34}$ The in situ interfacial reaction, however, proceeded along the entire $\mathrm{NiO}-\mathrm{BZCY} 4$ and SDC boundaries, which is insensitive to the surface roughness of respective layer. Thus, the formed
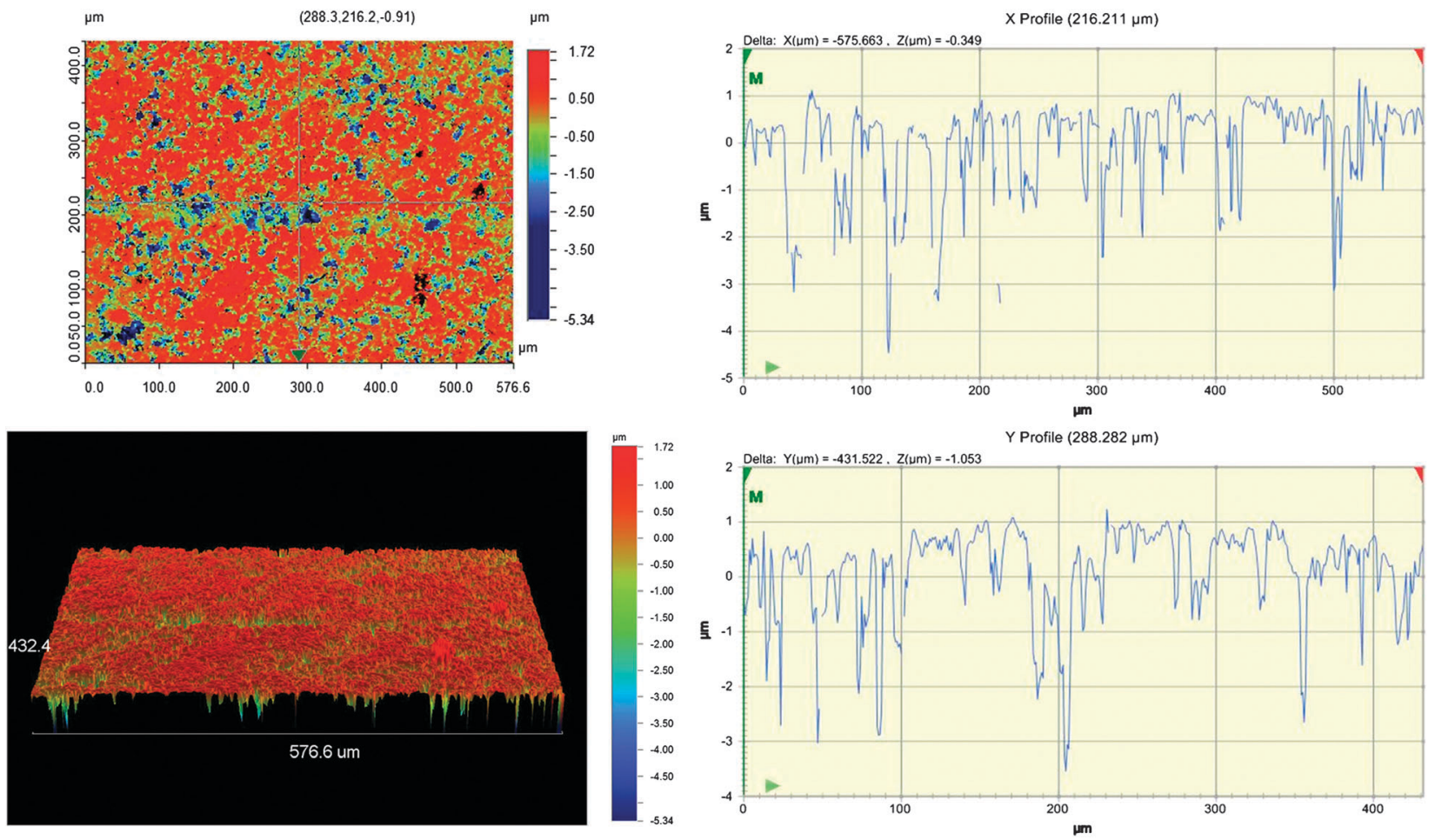

Fig. 8 The microstructural morphology of surface of a sintered NiO-BZCY4 anode substrate. 


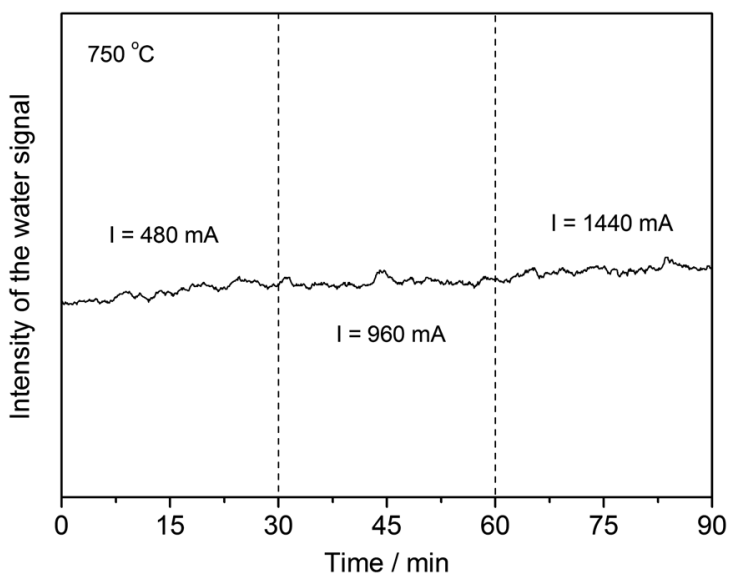

Fig. 9 The response of water signal to the different polarization current introduced to the Ni-BZCY4|SDC|BSCF cell at $750{ }^{\circ} \mathrm{C}$.

interfacial layer acted as a well separator for the NiO-BZCY4 anode and SDC electrolyte, leading to the obvious increase in OCV. Because of the very small thickness, such a blocking layer did not cause significant increase in the cell ohmic resistance. In addition, the large surface roughness is beneficial to increase triple phase boundary where the electrode reaction happens. Consequently, both high cell power output and OCV was successfully achieved.

Since SDC is an oxide ion conductor with negligible proton conductivity, the water was likely formed at the anode side for the $\mathrm{Ni}-\mathrm{BZCY} 4|\mathrm{SDC}| \mathrm{BSCF}$ cell, which was supported by the observation of condensed water at the cool part of the anode chamber outside the furnace during fuel cell operation. To further detect the water formation side, a micro quartz tube probe was put near the cathode surface which was connected with an on line mass spectrometer. Shown in Fig. 9 is the response of water signal to the polarization current. The introduction of polarization current to the fuel cell would cause the formation of water. No any change in intensity of the water signal with the polarization current density was observed, implying all water was produced at the anode side. It suggests the interfacial layer formed should also possess oxide ion conductivity. Indeed some protonic conductors were reported to show mixed proton and oxide ion conductivity at fuel cell operation conditions. ${ }^{35-37}$

For practical application, high operational stability is required. For the performance stability test, the Ni-BZCY4|SDC|BSCF cell was first polarized under a constant polarization current density of $750 \mathrm{~mA} \mathrm{~cm}^{-2}$ for a certain period at $600{ }^{\circ} \mathrm{C}$. Then, $I-V$ polarization tests at various temperatures were conducted. After that, the cell was re-polarized at the constant current density of $750 \mathrm{~mA} \mathrm{~cm}{ }^{-2}$ at $600{ }^{\circ} \mathrm{C}$ for a selected period and the $I-V$ polarization test at various temperatures was repeated several times. Fig. 10a shows the time dependence of the power density at constant polarization current density of $750 \mathrm{~mA} \mathrm{~cm} \mathrm{~cm}^{-2}$ at $600{ }^{\circ} \mathrm{C}$, while the $I-V$ and $I-P$ polarization curves during the different periods are shown in Fig. 10b-d. Under the polarization at constant current density, a first slight decrease in cell voltage (thus the power output) was observed at the initial period when the polarization was induced. As demonstrated previously, the cathodic current polarization
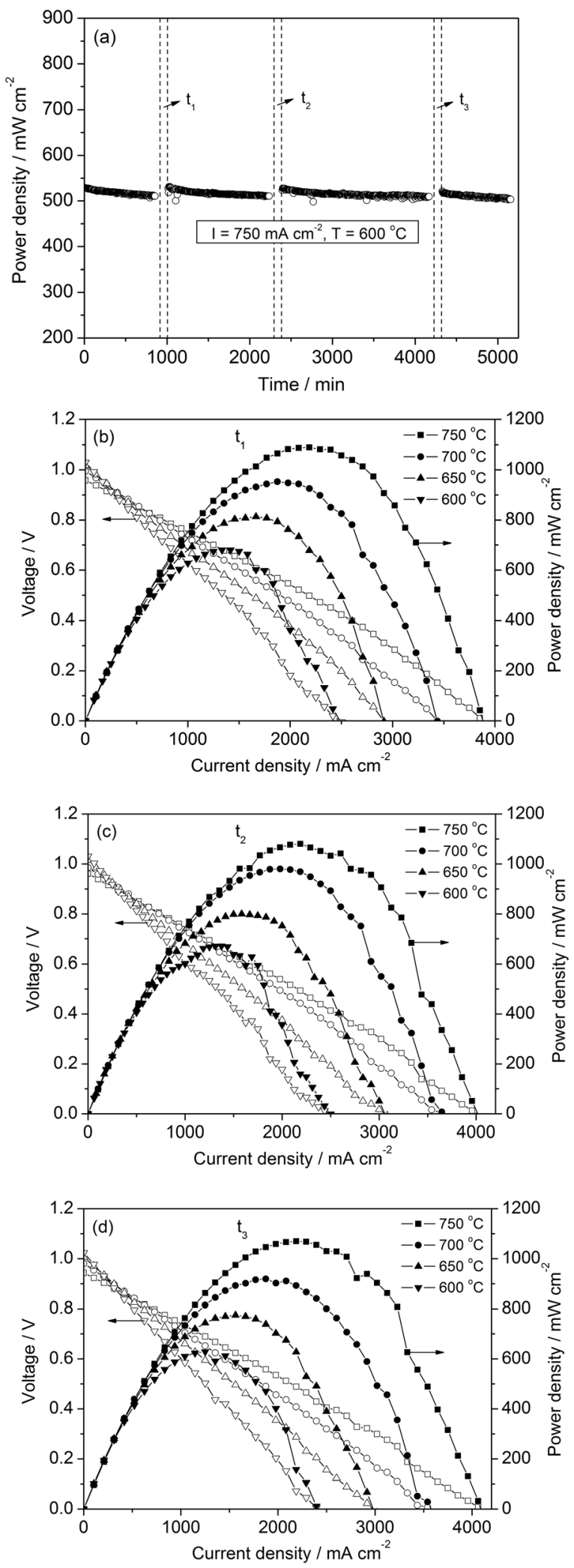

Fig. 10 (a) The time dependence of the power density of the $\mathrm{Ni}-$ BZCY4 $|\mathrm{SDC}| \mathrm{BSCF}$ cell at constant polarization current density of $750 \mathrm{~mA} \mathrm{~cm}^{-2}$ at $600{ }^{\circ} \mathrm{C}$. (b-d) $I-V$ and $I-P$ polarization curves of this cell during the different periods.

led to the production of water vapor at the anode side, which leads to the increase of the proton conductivity and the 


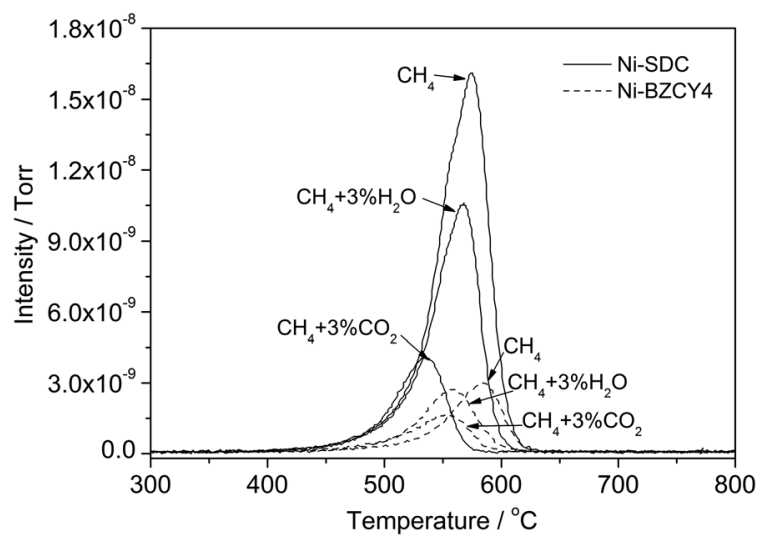

Fig. 11 The $\mathrm{O}_{2}-\mathrm{TPO}$ profiles of both $\mathrm{Ni}-\mathrm{SDC}$ and Ni-BZCY4 anode (pre-fired at $1450{ }^{\circ} \mathrm{C}$ for $5 \mathrm{~h}$ ) after treatment in pure $\mathrm{CH}_{4}, \mathrm{CH}_{4}+3 \% \mathrm{H}_{2} \mathrm{O}$, and $\mathrm{CH}_{4}+3 \% \mathrm{CO}_{2}$ for $1 \mathrm{~h}$ at $600{ }^{\circ} \mathrm{C}$, respectively.

decrease of the oxide ion conductivity of both the anode layer and also the formed interfacial layer. As a result, the cell performance was reduced slightly until the water concentration in the anode atmosphere was stabilized. As a whole, the fuel cell performance is fairly stable based on the results in Fig. 10 .

One significant advantage of SOFCs over low-temperature fuel cells is the fuel flexibility. In principle, SOFCs can operate on any combustible fuels. However, coking is a serious problem encountered by conventional SOFC with nickel cermet anode when operating on hydrocarbon fuels. ${ }^{38}$ The carbon deposition behavior of Ni-BZCY4 and Ni-SDC anodes were comparatively studied by first treating both anode materials in powder form (pre-fired at $1450{ }^{\circ} \mathrm{C}$ for $5 \mathrm{~h}$ ) in a flowing pure $\mathrm{CH}_{4}, \mathrm{CH}_{4}+3 \% \mathrm{H}_{2} \mathrm{O}$, or $\mathrm{CH}_{4}+$ $3 \% \mathrm{CO}_{2}$ for $1 \mathrm{~h}$ at $600{ }^{\circ} \mathrm{C}$. Then, the deposited carbon over the anode catalysts was analyzed by temperature programmed oxidation in an flow oxygen atmosphere $\left(\mathrm{O}_{2}-\mathrm{TPO}\right)$. The corresponding $\mathrm{O}_{2}-$ TPO profiles are shown in Fig. 11. There is less carbon deposited over the Ni-BZCY4 anode than the $\mathrm{Ni}-\mathrm{SDC}$ anode after the treatment in the same atmosphere for the same period. For example, the $\mathrm{CO}_{2}$ peak areas are $9.53 \times$ $10^{-7}, 6.10 \times 10^{-7}$ and $2.50 \times 10^{-7}$ for the Ni-SDC anode after the treatment in pure $\mathrm{CH}_{4}, \mathrm{CH}_{4}+3 \% \mathrm{H}_{2} \mathrm{O}$, and $\mathrm{CH}_{4}+$ $3 \% \mathrm{CO}_{2}$, respectively, while the corresponding values are $1.97 \times 10^{-7}, 1.83 \times 10^{-7}$ and $1.31 \times 10^{-7}$ for the Ni-BZCY4 anode. This suggests that the Ni-BZCY4 anode has higher coking resistance than $\mathrm{Ni}-\mathrm{SDC}$ anode when operating on pure hydrocarbon fuels or under internal reforming conditions, which is an additional benefit for ensuring a long operational stability.

\section{Conclusions}

In summary, by simply changing the ionic conducting phase in the anode into proton-conducting $\mathrm{BaZr}_{x} \mathrm{Ce}_{\mathrm{y}} \mathrm{Y}_{1-x-y} \mathrm{O}_{3}$ oxide, the OCV of anode-supported thin-film doped ceria electrolyte fuel cells at temperatures over $600{ }^{\circ} \mathrm{C}$ can be substantially improved while the cell output can still maintain a high level. A power density of $462 \mathrm{~mW} \mathrm{~cm}^{-2}$ at $0.7 \mathrm{~V}$ was successfully achieved at $600{ }^{\circ} \mathrm{C}$, which is comparable to a similar cell with sole SDC electrolyte and much higher than the fuel cell with $\mathrm{BaZr}_{0.4} \mathrm{Ce}_{0.4} \mathrm{Y}_{0.2} \mathrm{O}_{3}$ protonic conducting electrolyte. This intriguing cell concept may be a practical way to develop new high performance SOFCs for efficient power generation with great environmental benignity.

\section{Acknowledgements}

This work was supported by the "National Science Foundation for Distinguished Young Scholars of China" under contract No. 51025209 and the Project Funded by the Priority Academic Program Development of Jiangsu Higher Education Institutions.

\section{Notes and references}

1 N. Q. Minh, J. Am. Ceram. Soc., 1993, 76, 563-588.

2 Z. Cheng, J.-H. Wang, Y. M. Choi, L. Yang, M. C. Lin and M. L. Liu, Energy Environ. Sci., 2011, 4, 4380-4409.

3 S. C. Singhal, Solid State Ionics, 2002, 152-153, 405-410.

4 A. Mitterdorfer and L. J. Gauckler, Solid State Ionics, 1998, 111, $185-218$.

5 C.-C. T. Yang and W.-C. J. Wei, J. Am. Ceram. Soc., 2004, 87, $1110-1116$.

6 Y. B. Zhou, B. M. An, Y. M. Guo, R. Ran and Z. P. Shao, Electrochem. Commun., 2009, 11, 2216-2219.

7 B. C. H. Steele and A. Heinzel, Nature, 2001, 414, 345-352.

8 D. J. L. Brett, A. Atkinson, N. P. Brandon and S. J. Skinner, Chem. Soc. Rev., 2008, 37, 1568-1578.

9 E. Fabbri, L. Bi, D. Pergolesi and E. Traversa, Energy Environ. Sci., 2011, 4, 4984-4993.

10 S. de Souza, S. J. Visco and L. C. De Jonghe, Solid State Ionics, 1997, 98, 57-61.

11 L. Yang, C. D. Zuo, S. Z. Wang, Z. Cheng and M. L. Liu, $A d v$. Mater., 2008, 20, 3280-3283.

12 E. Fabbri, A. D'Epifanio, S. Sanna, E. D. Bartolomeo, G. Balestrino, S. Licoccia and E. Traversa, Energy Environ. Sci., 2010, 3, 618-621.

13 H. Matsumoto, Y. Kawasaki, N. Ito, M. Enoki and T. Ishihara, Electrochem. Solid-State Lett., 2007, 10, B77-B80.

14 K.-D. Kreuer, Chem. Mater., 1996, 8, 610-641.

15 C. S. Ding and T. Hashida, Energy Environ. Sci., 2010, 3, $1729-1731$.

16 Z. L. Zhan, D. M. Bierschenk, J. S. Cronin and S. A. Barnett, Energy Environ. Sci., 2011, 4, 3951-3954.

17 Y. S. Xie, R. Neagu, C. S. Hsu, X. G. Zhang and C. Deĉes-Petit, J. Electrochem. Soc., 2008, 155, B407-B410.

18 M. Mogensen, N. M. Sammes and G. A. Tompsett, Solid State Ionics, 2000, 129, 63-94.

19 K. L. Duncan, K.-T. Lee and E. D. Wachsman, J. Power Sources, 2011, 196, 2445-2451.

20 A. Tomita, S. Teranishi, M. Nagao, T. Hibino and M. Sano, J. Electrochem. Soc., 2006, 153, A956-A960.

21 D. Hirabayashi, A. Tomita, S. Teranishi, T. Hibino and M. Sano, Solid State Ionics, 2005, 176, 881-887.

22 L. Zhao, B. B. He, J. C. Shen, F. L. Chen and C. R. Xia, Electrochem. Commun., 2011, 13, 450-453.

23 Y. Y. Rao, Z. Q. Wang, W. Zhong, R. R. Peng and Y. L. Lu, J. Power Sources, 2012, 199, 142-145.

24 Z. P. Shao and C. Su, A system of solid oxide fuel cell and its preparation method, CN201010018272.6, Nanjing University of Technology, 2010.

25 Z. P. Shao and S. M. Haile, Nature, 2004, 431, 170-173.

26 Q. L. Liu, K. A. Khor and S. H. Chan, J. Power Sources, 2006, 161, 123-128.

27 Z. M. Zhong, Solid State Ionics, 2007, 178, 213-220.

28 K. Katahira, Y. Kohchi, T. Shimura and H. Iwahara, Solid State Ionics, 2000, 138, 91-98.

29 C. D. Zuo, S. W. Zha, M. L. Liu, M. Hatano and M. Uchiyama, Adv. Mater., 2006, 18, 3318-3320. 
30 Y. Lin, R. Ran, Y. Zheng, Z. P. Shao, W. Q. Jin, N. P. Xu and J. Ahn, J. Power Sources, 2008, 180, 15-22.

31 Q. S. Zhu, T. A. Jin and Y. Wang, Solid State Ionics, 2006, 177, 1199-1204.

32 C. J. Zhang, H. L. Zhao and S. Y. Zhai, Int. J. Hydrogen Energy, 2011, 36, 3649-3657.

33 Y. M. Guo, R. Ran and Z. P. Shao, Int. J. Hydrogen Energy, 2011, 36, 1683-1691.
34 Z. S. Duan, M. Yang, A. Y. Yan, Z. F. Hou, Y. L. Dong, Y. Chong, M. J. Cheng and W. S. Yang, J. Power Sources, 2006, 160, 57-64. 35 L. Yang, S. Z. Wang, K. Blinn, M. F. Liu, Z. Liu, Z. Cheng and M. L. Liu, Science, 2009, 326, 126-129.

36 R. Haugsrud and T. Norby, Nat. Mater., 2006, 5, 193-196.

37 A. Tomita, T. Hibino and M. Sano, Electrochem. Solid-State Lett., 2005, 8, A333-A336.

38 S. Mclntosh and R. J. Gorte, Chem. Rev., 2004, 104, 4845-4865. 